\title{
The Role of Partnership Guidance on Increasing the Economy of Workers the Sea Cucumber Business in Benan Village Katang Bidare District Lingga Regency
}

\author{
Akhirman $^{1}$, Lia Suprihartini ${ }^{2}$, Dian Putri Ramadhani ${ }^{3}$ \\ \{ ${ }^{1}$ akhirman@umrah.ac.id, ${ }^{2}$ lia.arai@gmail.com, ${ }^{3} 170564201011 @$ student.umrah.ac.id $\}$ \\ ${ }^{1,2,3}$ Raja Ali Haji Maritime University
}

\begin{abstract}
Planning or already owning a sea cucumber farming business in the Riau Islands does not always run smoothly, even though the price of sea cucumbers in domestic and foreign markets such as the Singapore market is expensive. residents failed to try because of lack of knowledge. The managers earn an average income of 1 to $1.5 \mathrm{million} / \mathrm{harvest}$ from 500 sea cucumbers that are produced/harvested. Managers will earn between 4 to 4.5 million from 1000 sea cucumbers produced/harvested. Same with the income of the company's leaders in the city. Independent workers and those who work in groups receive a wage of Rp. $1,500,000 / 500$ sea cucumbers or Rp. 3,000/head to clean the entrails and skin. Each group has 9 workers so each of them will receive an income of Rp. 167,000/harvest activity or per 500 sea cucumbers. If workers are able to clean 1000 sea cucumbers in a maximum of 3-4 hours the manager pays IDR 3,000,000 for 9 people, equal to a wage of Rp. 333.333/person. The 2021 UMP (Provincial Minimum Wage) is Rp. 3,005,383 per month. Therefore, workers in the sea cucumber business are able to earn more than the UMP. As a result, the development of the sea cucumber business has had a positive impact on the economy of Benan Village. Whereas before there was a sea cucumber business. Workers at the company receive wages in accordance with the 2021 UMP, which is $3,005,383$ and can be more than the UMP. The development of the sea cucumber business has an effect on the economy of the community (work) of Benan Village.
\end{abstract}

Keywords: Business Partnership, Workers' Economy, Sea Cucumber Business.

\section{Introduction}

\subsection{Background Information}

Planning or owning a sea cucumber business brings its own blessings to the people of Benan Village, Katang Bidare District, Lingga Regency. Teripang Kepri high quality dry sea cucumber (Holuthuriascabra). Enlargement efforts in the Riau Islands are still small, while the selling price according to data from PT. Inodovare which is based in Batam. Dried sea cucumbers of 70-80 fish $/ \mathrm{kg}$ (dry) can be sold at a price of Rp. 2,000,000.00. The highest price is Dried Sea 
Cucumber of 20-30 units/kg which can be sold at a price of Rp. 2,750,000.00, PT. Indovare Batam (2021).

Planning or owning a business of raising sea cucumbers in the Riau Islands does not always run smoothly. Although the price of sea cucumbers in domestic and foreign markets, such as the Singapore market, is expensive this does not increase the motivation of fishermen to run this business. In addition to the cost of making cages, procuring seedsand the risks involved, it take 812 month for sea cucumber to grow to the size for selling. The results of interviews conducted by researchers with several managers of sea cucumber farm business stated that few of the island's residents were successful in running this business. To understand the reasons for this, the authors conducted limited research titled "The Role of Partnership Guidance on Increasing the Economy of Workers in the Sea Cucumber Business in Benan Village, KatangBidare District, Lingga Regency".

According to PraptoDarsono (2007), sea cucumbers are specific and easily recognizable groups of marine biota. A sea cucumber's body shape is generally cylindrical, extending from the tip of the mouth to the anus (orally-aborally). The mouth is located at the front end (anterior), and the anus is at the rear end (posterior). According to Gajali Husain, et al (2017), sea cucumbers are a group of marine invertebrate animals from the class Holothuroidea, phylum Echinoderms that are often found in coral reefs. Since their body shape is generally like a cucumber, their common name is "Sea Cucumber". Another characteristic of sea cucumbers is that these animals move slowly and their rough skin has limestone plates and small spines. Sea cucumbers usually live in coastal areas and in the deep sea to a depth of about $366 \mathrm{~m}$. (kkp.go.id, 2021). Natural ingredients produced by sea cucumbers are anti-bacterial and anti-mold Kaswandi et al. (2000), Lian et al. (2000) and Kustiariyah et al. (2006). The main habitat for sea cucumbers is in the area of seagrass beds, coral reefs and the open area. (kkp.go.id, 2021). Healthy environmental conditions are a key factor for the preservation of marine life, including sea cucumbers. According to Martoyo et al. (2007) the optimal water temperature for the growth of sea cucumbers is between 24 and $30^{\circ} \mathrm{C}$, salt content of 28-32 ppt, water $\mathrm{pH}$ 6.5-8.5, dissolved oxygen 4-8 ppm, a current velocity of 0,3$0,5 \mathrm{~m} / \mathrm{s}$ and $50-150 \mathrm{~cm}$ brightness. Sea cucumbers are very sensitive to sunlight.

The distribution of live sea cucumbers is very wide and is most commonly found in the Indo-West Pacific region. Sea cucumbers are found in various colors including black, white, gray and striped. Sea cucumbers are generally consumed in processed forms, such as dried gonads (konoko), dried intestines (konowata) or crackers. Sea cucumbers contain active substances that are useful in the pharmaceutical and health fields. Currently, the sea cucumber trade has expanded, especially in Hong Kong and Singapore, which are two of the world's sea cucumber export trade centers. Dried sea cucumbers have been processed and traded in the USA, Canada, Europe, Taiwan, the Republic of Korea, China, Australia, Malaysia and Thailand, among others (Kustiariyah, 2007).

There are 1200 species of sea cucumbers in the world. 30 of which are included in the sea cucumber group which can be seen taxonomically in the Marine Species Identification. Of these 650 species of sea cucumbers, $10 \%$ are found in Indonesia. Of the total species of sea cucumbers, the following are five types of sea cucumbers are classified as having a high selling value, namely: (kkp.go.id, 2021).

1. Black Sea Cucumber (Holothuria edulis);

2. Koro Sea Cucumber (Holothurianobilis);

3. Pineapple Sea Cucumber (Thelonotaananas); 
4. Gamat Sea Cucumber (Stichopusnoctivatus);

5. Sand Sea Cucumber (Holothuriascabra).

\subsection{Benefits of Sea Cucumbers}

The benefits of sea cucumbers is not only as an economic source because they have a high selling value, but also as one of the key biota for the balance of shallow water ecosystems. Sea cucumbers eat sediment (they are deposit feeders) which serves as a bioturbator by processing the sediment in shallow water ecosystems. It is through this way of eating that sea cucumbers benefit the environment. The presence of remnants of organic matter, bacteria and microalgae contained in the sediment is the main food of sea cucumbers so that the accumulation of these substances in nature can be prevented due to the eating process. Sea cucumbers are detritus-eating animals, namely eating by sweeping sand into the mouth. The slow movement of sea cucumbers causes these animals to have an efficient body defense mechanism, namely by releasing toxic holothurins and can paralyze small animals (Kustiariyah, 2007). Due to their eating process sea cucumbers maintain the balance of the ecosystem. The species Holothuriaatra (in local language they are known as the black sea cucumber) is capable of processing up to $19 \mathrm{~kg}$ of dry sediment/year/individual. Sea cucumbers are also thought to have a function as one of the obstacles to ocean acidification. A water column contains $\mathrm{CaCO} 3$, which over a certain period of time will settle to the bottom of the water. This area will then become very tight due to the accumulation of organic matter. The existence of sea cucumbers that eat sediment serve an ecological function in releasing it back in the form of feces; the sediment will be loose and $\mathrm{CaCO} 3$ will be released back into the water column to be utilized by the corals to form reefs (kkp.go.id, 2021).

Sea cucumbers are one of the most sought after marine commodities because they have properties that are believed to maintain health for humans. A sea cucumber's body contains high collagen fibers, which can accelerate wound healing. In addition, sea cucumbers are also used as traditional medicine to treat damage to the working system of the kidneys, reproductive organs, and gastrointestinal tract. The taste is salty and warming, leading sea cucumbers to often be consumed to treat symptoms of weakness after illness or physical weakness due to aging. Traditionally, the consumption of sea cucumbers by Chinese people around the world is more to take advantage of its medicinal properties. (kkp.go.id, 2021).

\subsection{Sea Cucumber Farming}

Sea Cucumber Farming have several stages, starting from a business plan, sourcing business capital, choosing a business location, making cages, sourcing seeds, maintaining seedling growth, production or harvesting, processing before being marketed, and selling (marketing). These stages are in principle the same as agricultural businesses on land as in addition to business capital, there is a long period of time before the harvest. 
Researchers conducted a study on the results of student research creativity program in 2020, namely The Guidance of Sea Cucumber Farming Business in Benan Village, KatangBidare District, Lingga Regency, Riau Archipelago Province.

\section{Step One;}

Conduct education (communicate directly between researchers and business managers), related to the Location and Feasibility of the Sea Cucumber Farming Business. From the literature read, it is explained that sea cucumbers are marine animals that live naturally and are easily farmed. The location of the sea cucumber farming affects the growth of the sea cucumbers themselves. There are several location criteria that need to be considered in sea cucumber farming (kkp.go.id, 2021), namely:

1. The bottom of the water consists of sand.

2. Muddy sand is overgrown with seagrass.

3. At low tide, water maintains a depth of $40-80 \mathrm{~cm}$.

4. The water clarity is above $75 \mathrm{~cm}$.

5. The current is not too strong and the area is protected from strong winds.

6. The waters are not polluted and easily accessible.

7. Salinity is between 24 and 33 ppt and the temperature range is $25-30^{\circ} \mathrm{C}$.

A sea cucumber farm is usually built of a wooden or bamboo cage with a net surrounding it. The nets used can be made of nylon with an eye size of $0.2 \mathrm{~cm}$ and are embedded into the surface of the seabed to prevent the sea cucumbers from escaping.

\section{Step Two;}

Guiding business actors to calculate all costs incurred for the sea cucumber farming business. Calculating the value of the investment, how much does it cost to make a plugged net cage, along with the seeds to produce or harvest. Because for the manufacture of cage nets, managers need work equipment such as; boats, mattock, shovels, chopper, saws, buckets, and medicines such as; first aid kits, gasoline fuel. Also a raw materials for making cage nets such as; minimum land area of $10 \mathrm{~m}^{2} \times 15 \mathrm{~m}^{2}$, wood, waring, nails, nylon for fastening, burlap sack which will be filled with paris to hold the net on the bottom of the cage. Seedlings; Sea cucumber seeds for the size of a net cage with an area of $150 \mathrm{~m}^{2}$ normally can be filled with sea cucumber seeds between 800 to 1000 unit or sea cucumber seeds measuring between $40-60$ grams/head, normally the density of sea cucumbers is between $6-8 \mathrm{unit} / \mathrm{m}^{2}$ or the size of the seeds with weight between 70-100 grams with a density of seeds that are stocked amounting to between 4-6 tails $/ \mathrm{m}^{2}$. (kkp.go.id, 2021).

The shape of the plugged net cage, the size of the cage, the material for making the cage that is used as shown in the picture below. 


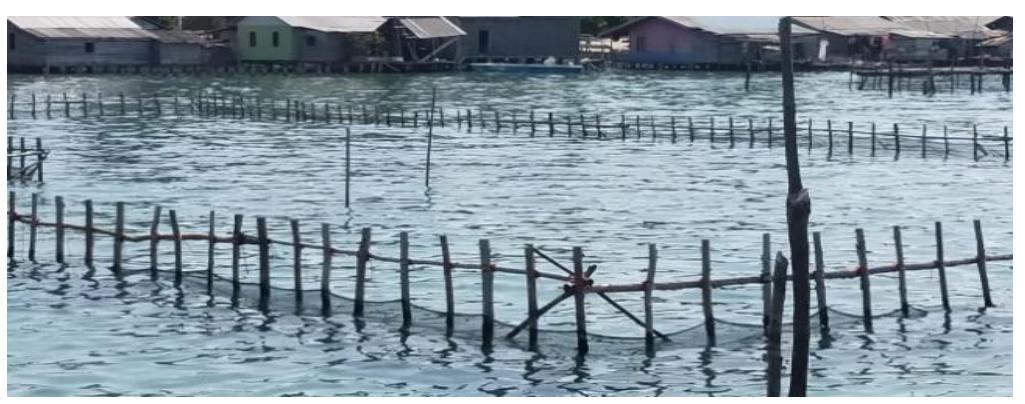

Fig.1. Personal Document (2020)

The manufacture of a sea cucumber cage $10 \mathrm{~m}^{2} \times 15 \mathrm{~m}^{2}$ costs between 13,000,000 and $16,000,000$ million rupiah. When choosing the location of a sea cucumber farm, one must consider several issues such as security, natural predators and the availability of a sand/mud base for their food source. Sea cucumbers generally prefer clear waters, the bottom of which is fine sand or sand mixed with mud and plants such as seagrass and seaweed that can protect them from direct sunlight.

\section{Step Three;}

Education for managers to carry out growth monitoring activities on sea cucumbers for 8 to 12 months or more. Since sea cucumbers do not require special monitoring unlike farming a fish. Monitoring the netting of the sea cucumbers'cage is required at least once a day. If material such as wood hits the net it could be damaged or predatory animals such as eagles and crabs may enter the cage. Monitoring can be done at low tide or high tide as shown in the following image.

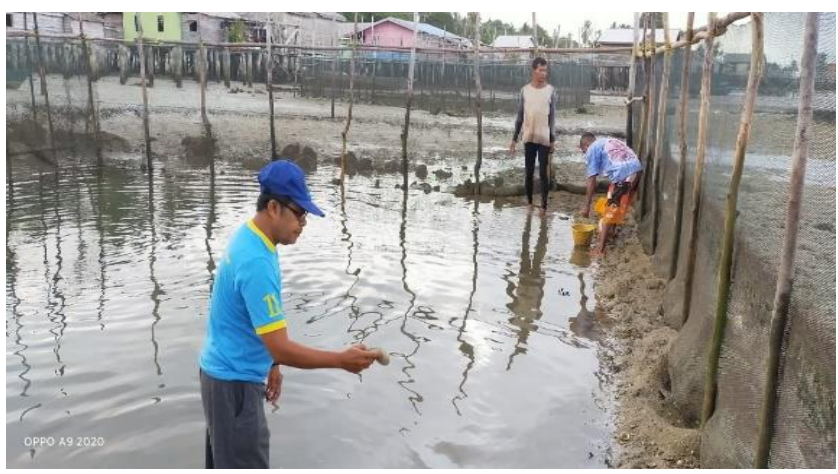

Fig.2. Direct Monitoring (doc.2020)

In addition to monitoring the cage environment, managers should measure the size and weight of the sea cucumbers.

\section{Step Four;}


Sea cucumbers are ready to be harvested when they measure between \pm 20 and $25 \mathrm{~cm}$ and weigh $>600$ to $800 \mathrm{~g} / \mathrm{unit}$.

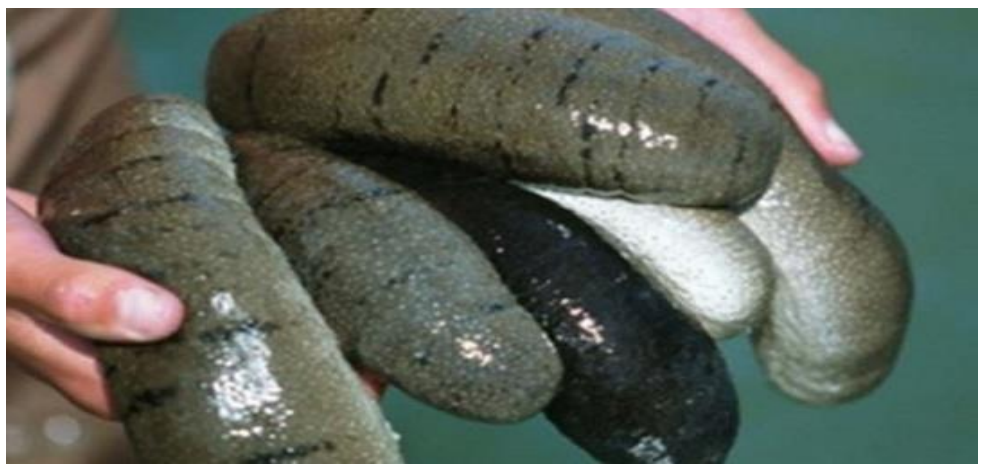

Fig.3. Sea cucumber weight 600-800 grams/unit (doc/ 2021)

The main problem that causes sea cucumbers to experience growth delays is when the environment of the farm is not suitable. During low tide, sea cucumbers can survive on the surface of the mud for 6-10 hours. However, in order for sea cucumbers to grow faster, a digging depth of between $80-100 \mathrm{~cm}$ is needed in a minimum area of $2 \mathrm{~m}^{2}$ Therefore, the location of the farm must have enough sand mixed with the mud.

\section{Step Five;}

To maintain the good quality of sea cucumbers and sell them at a higher price, attention must be paid to the sea cucumber processing. Education for Sea Cucumber Processing activities,

\section{Purification of Sea Cucumbers}

Purification of sea cucumber is done by cleaning the sea cucumber entrails after being removed from the pond. The fresh sea cucumbers entrails are removed in order to avoid the process of spoilage in sea cucumbers because the entrails contain microorganisms that can cause rot in sea cucumbers. The process of decay that occurs is characterized by the appearance of an unpleasant odor and the loss of flexibility of the sea cucumber meat so that the sea cucumber becomes mushy and not chewy (Herliany, et al, 2016).

\section{Repeated Boiling}

Sea cucumbers that have been cleaned it entrails, then boiled. Boiling sea cucumbers aims to extend the shelf life of the sea cucumbers. There are many versions and methods of boiling sea cucumbers. Traditionally, in boiling there are those using sea water/fresh water and it is done with three boiling times (Herliany, et al, 2016). The following is the activity of boiling sea cucumbers that have been taken from their cages. 


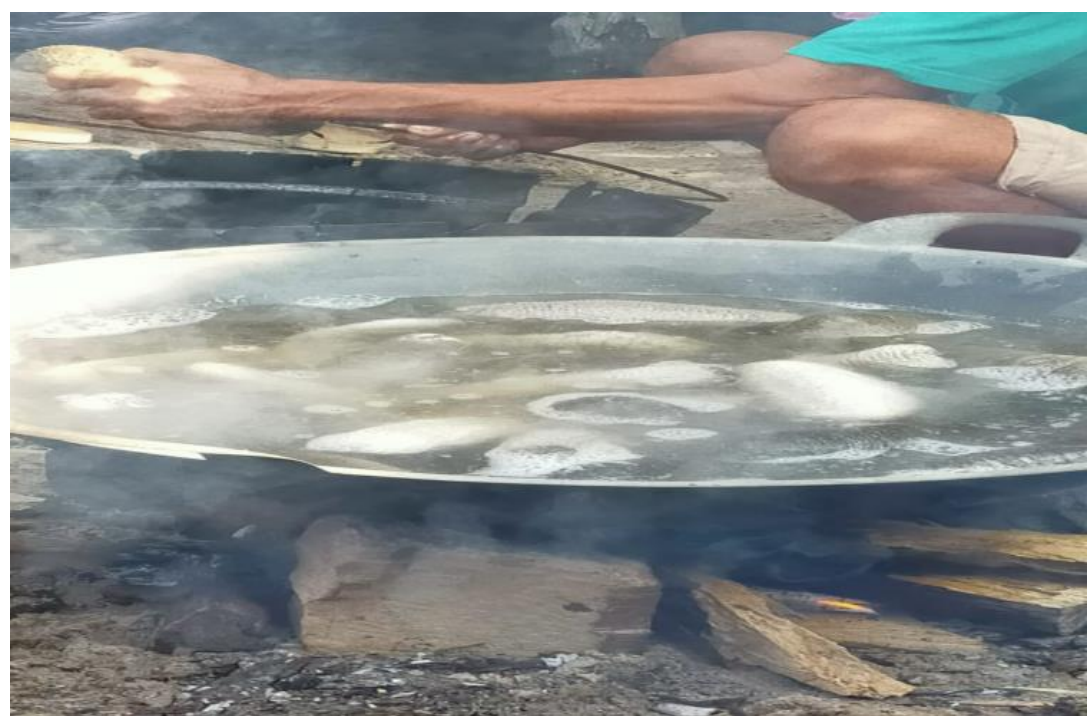

Fig.4.. Sea cucumber boiling activity (doc.2020)

In the first boiling the sea cucumbers are boiled at a water temperature of around $60^{\circ} \mathrm{C}$ for 15-20 minutes, this is so that the sea cucumber skin is not damaged. The first boiling of this sea cucumber will also produce a supple sea cucumber skin texture so that later it will facilitate the process of cleaning the sea cucumber skin. The first boiling with a high temperature is not recommended, because it will have an impact on the final result of the sea cucumber where there will be damage to the sea cucumber skin.

After the boiling process for approximately 30 minutes, the sea cucumbers are then washed with clean water to remove the sand (lime) attached to the sea cucumber skin. The process of cleaning sea cucumbers from lime (sand) attached to the skin requires at least 6 to 8 workers to clean sea cucumbers with an amount of between 100-200 fish per day. The results of the cleaned sea cucumbers can be seen in the following picture.

The second boiling is carried out at a temperature of $100^{\circ} \mathrm{C}$ or boiling mixed with chopped papaya leaves or noni fruit. Boiling is done about 30 minutes. Boiling with high temperatures is intended so that microorganisms that are resistant to high temperatures can die so that the decay process does not occur. The papaya leaves used are useful to facilitate the process of removing the lime layer on the sea cucumber skin. The removal of the lime layer traditionally uses papaya leaves, papaya fruit or gadung leaves. These three ingredients are known to contain the papain enzyme which functions to facilitate the removal of the lime layer on the sea cucumber skin.

\section{Cleaning the Sea Cucumber Skin From the Attached Lime (Sand).}

The cleaning of the sea cucumber skin is carried out between the boiling process of the sea cucumbers. Each time the boiling is finished at the specified time, the sea cucumber skin is cleaned with a brush made of fibers / other soft materials. Cleaning is carried out with certain 
techniques to keep the sea cucumbers from being damaged. Brushes made from hard materials such as metal need to be avoided, so as not to damage the cleaned sea cucumber skin. Cleaning the sea cucumber skin aims to remove microorganism dirt and lime that sticks to the sea cucumber skin. Here is a picture of a sea cucumber that has been cleaned of stomach contents and skin.

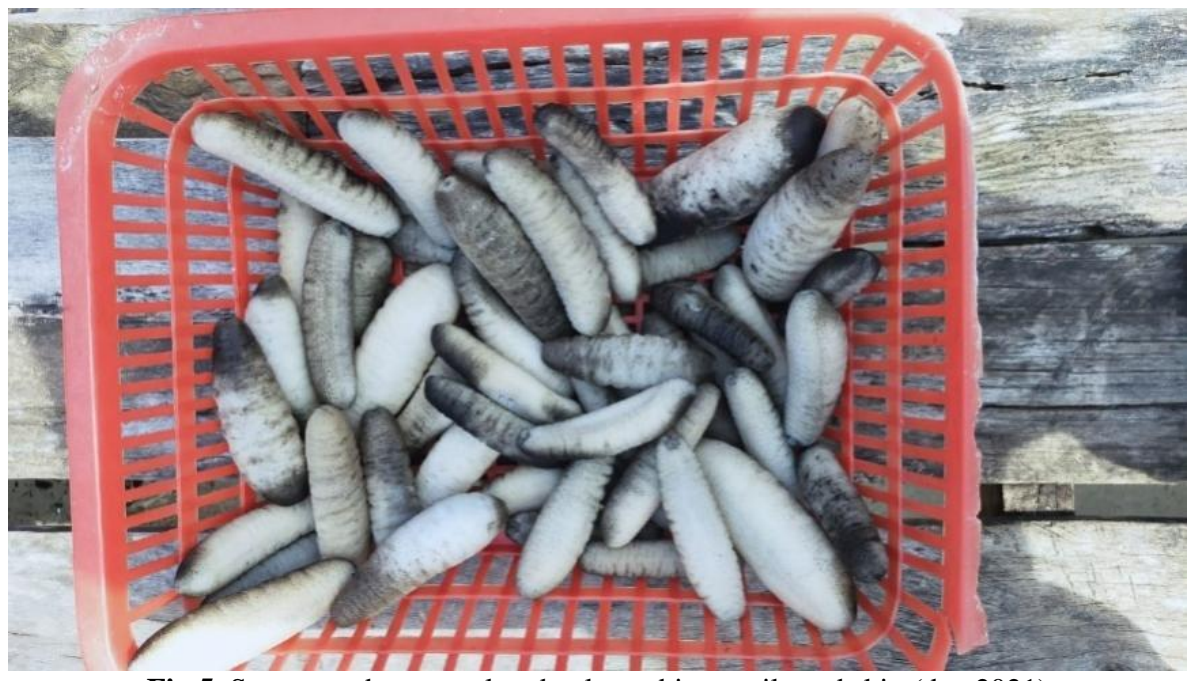

Fig.5. Sea cucumbers are already cleaned it entrails and skin (doc.2021)

Removal of the entrails of sea cucumbers traditionally is usually done by splitting the stomach (ventral) of the sea cucumber, starting from the anus to the mouth (along the body of the sea cucumber). However evisceration belly can also be done by cutting $1 \mathrm{~cm}$ in the anus. This is done to minimize the visible incision marks on the dried sea cucumber products. The sea cucumbers that have been gutted then washed clean to remove dirt attached to the body of the sea cucumber. Washing is also done on the inside of the sea cucumber, so that the remaining contents of the stomach are completely clean. Washing is done using clean water to maintain the hygiene of the resulting product. (Herliany, et al, 2016).

\section{Drying On Sea Cucumber}

Drying on sea cucumbers is the last process of a sea cucumber processing. Drying on sea cucumbers aims to remove the water content in the body of sea cucumbers to a minimum, so that sea cucumbers can be stored for a long time. As is known, the body of sea cucumbers is dominated by water. Products with high water content are susceptible to microbial attack so that quality declines more quickly (Herliany, 2011). Some of the advantages of drying include that the material becomes more durable with a smaller volume of material size so as to simplify and save transportation and packing space, thus it is expected that production costs will be cheaper. Drying sea cucumbers also changes its texture to hard like a rock. This hard texture will prevent the emergence of mold during the storage period of dried sea cucumbers (Purcell, 2014). According to Sasongko (2015), the drying process can affect the weight of the final product. The drier the 
product, the lower the water content in the product, so the weight is also lower. Hutomo (1997) in his research suggested that there was a decrease in the weight of dry sea cucumbers around $96 \%$ of the initial weight (fresh sea cucumbers). Sea cucumbers that have gone through several processes, the last process of the most complicated business management activity is drying. The dried sea cucumbers can be seen in the following picture.

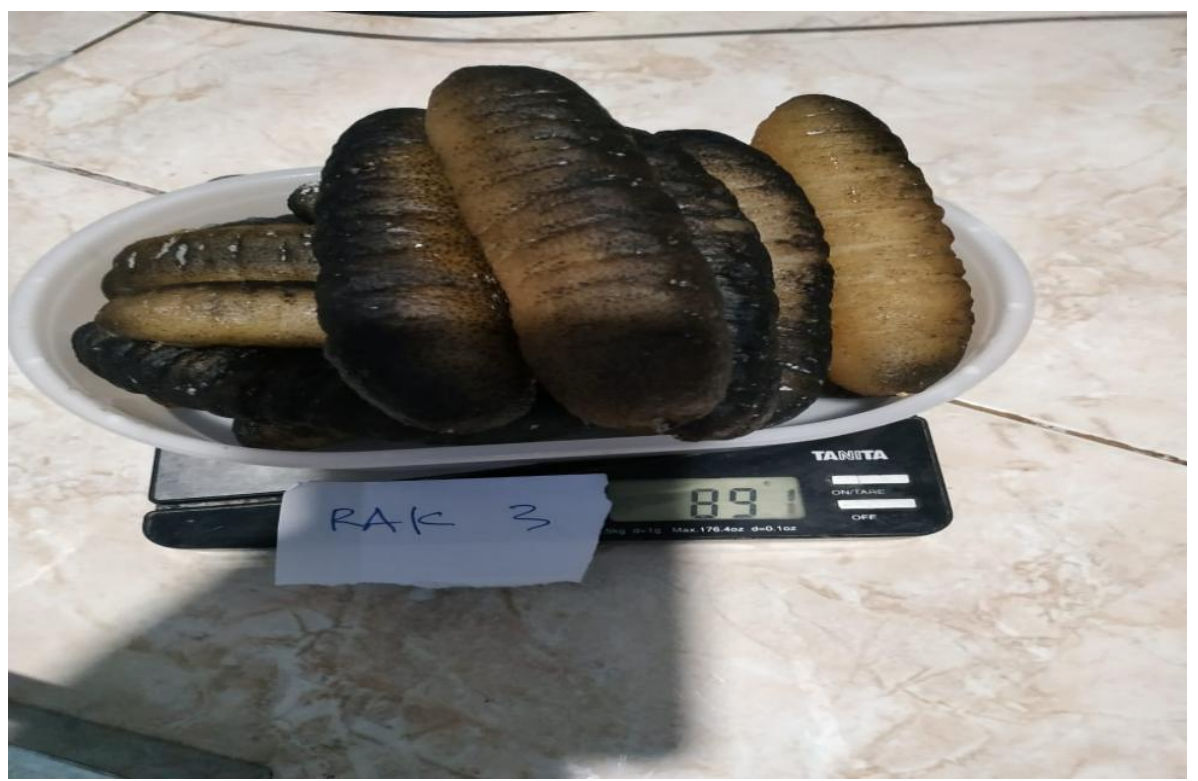

Fig.6. Dried sea cucumber (doc. 2020)

There are two methods of drying sea cucumbers, namely by using sunlight and drying using a drying machine. Drying sea cucumbers in the sun usually takes 2-3 days until the sea cucumbers are completely dry. This traditional method is still widely found in Indonesia. This traditional method of drying sea cucumbers has the disadvantage that it takes a long time because of the high level of dependence on the weather. If the weather conditions are cloudy or rainy, it will extend the drying time of the sea cucumbers. 


\section{Framework}

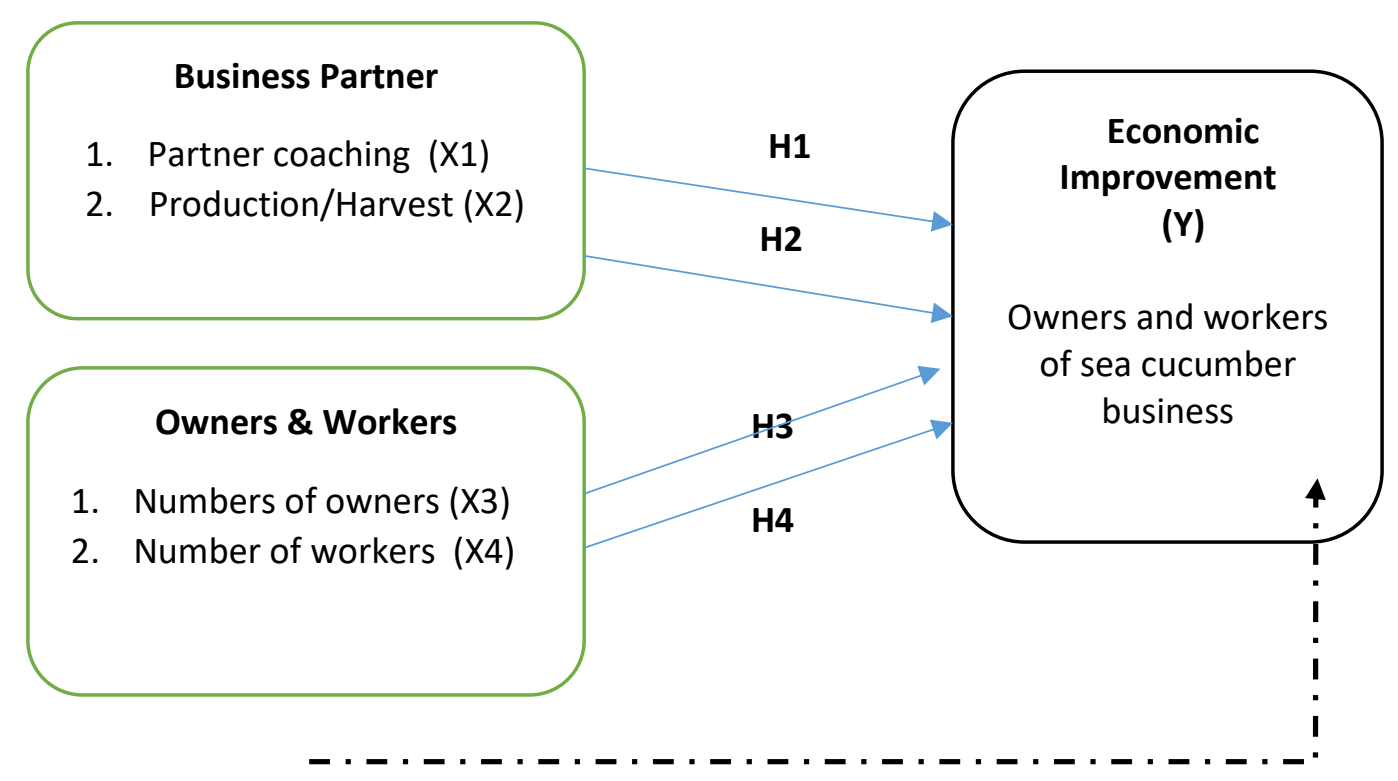

Fig.7. Framework (doc. 2020)

\subsection{Research Hypothesis}

Based on the background and problem formulation as well as description of the theoretical framework above, in this study the following hypotheses can be proposed as:

1. There is the effect of business partner development on the economic increase of actors and workers in the businesses of sea cucumber farming in Benan Village;

2. There are effects of the total production/harvesting of sea cucumber on the economic increase of activities and workers in the business of sea cucumber farming in Benan Village

3. There are effects of the number of business owners of sea cucumber farming towards the economic increase of activities and workers in the business of sea cucumber farming in Benan Village

4. There are effects of the number of workers in the business of sea cucumber farming towards the economic increase of the activities and workers in the business of sea cucumber farming in Benan Village

5. There are effects, collaboration, total production, number of business owners, number of workers on the business of sea cucumber farming on the economic improvement of the actors and the workers of the culture business in Benan Village. 


\section{Research Methods}

\subsection{Research Type}

This type of research uses descriptive qualitative research, which is to collect as much data as possible regarding the factors studied to find out their role (Arikunto, 2002: 86).

\subsection{Research Subject}

The material in this research is the analysis of customer satisfaction with service at The Body Art Surabaya. The subject of this research is the fisherman who manages the sea cucumber enlargement business. According to Arikunto (2006:134), research subjects that are less than 100, it is better to take all so that the research is a population study and if the number of subjects is large, it can be taken between $10-15 \%$ or $20-25 \%$ or more. For this reason, as subjects in this study, all business actors in the Benan Village area, Katang Bidare District, Lingga Regency totaled 8 people.

\subsection{Data Sources and Instruments}

Sources of data in research are research subjects, namely respondents, namely people who respond to or answer the questions of researchers, both written and oral questions (Arikunto, 2010:172). Primary data are data sources that directly provide data to data collectors (Sugiyono, 2011: 225), includes: a. Information on the characteristics of respondents, namely name, age, gender, education level, and occupation. b. Information regarding the level of expectation and quality of coaching (five dimensions of quality) from Lecturers of PKM UMRAH Tanjungpinang. Secondary data is a source that does not directly provide data to data collectors, such as documentation (Sugiyono, 2011:225). Research instruments are tools or facilities used by researchers in collecting data so that their work is easier and the results are better, in the sense of being more accurate, complete and systematic so that they are easier to process. The research instruments of researchers are: a. Respondent characteristics form (name, age, gender, education level and occupation). b. Questionnaire form on the level of consumer satisfaction with the implementation of coaching and improving business productivity.

\subsection{Collection Technique}

Data Researchers used data collection techniques such as the following: 1. Questionnaire. Questionnaire is a list of questions given to other people who are willing to respond (respondents) according to user requests. (Riduwan, 2003:25). Researchers will ask business actors to fill out the list of questions provided honestly and correctly. After being filled out by the respondent, the author will ask for the questionnaire again and examine the completeness of the contents. If the questionnaire has not been filled out completely, the author will ask the customer again to complete it. The researcher gave 2 questionnaires consisting of a questionnaire to measure the level of satisfaction and business productivity to measure the quality of service that came from the five dimensions of service quality. The questionnaire guidelines in this study were adopted from Tjiptono's book (2001:27) which can be seen in the following table : 
Variables used in this research is broadly divided into two variables, the dependent variable (dependent) and the independent variable (independent) to further clarify some of the variables used in this study can also be explained in the table below:

Table 1. Variable Operational Description of Business Partnership

\begin{tabular}{clll}
\hline Variable & \multicolumn{1}{c}{ Indicator } & Scala \\
\hline Business Development & 1. & Education, Business management. \\
$(\mathrm{X})$ & 2. & Calculating the value of investments & ordinal \\
& 3. & Determine the business location & \\
& 4. & Monitoring and growth of sea cucumbers. & \\
& 5. & Processing (harvest, production) & \\
\hline
\end{tabular}

Table 2. Variable Operational Description of Productivity

\begin{tabular}{cclc}
\hline Variable & \multicolumn{1}{c}{ Indicator } & Scala \\
\hline Productivity Boost(Y) & 1. & The number of people who work in the sea cucum & \\
& business & ordinal \\
\hline
\end{tabular}

Source: Data processed (2020)

\section{$4 \quad$ Results and Discussion}

Based on the distribution of questionnaires to the community managing Sea Cucumber rearing, various information was obtained as follows.

Table 3. Demographic Data of Business Managers.

\begin{tabular}{lc}
\hline \multicolumn{1}{c}{ Criteria } & Total \\
\hline Group of Sea Cucumber Business & 11 people x 1200 citizens \\
Company & 1 unit \\
\hline
\end{tabular}

From table 3. above, the community as the manager of the sea cucumber enlargement business is carried out in groups or more than one person in one business unit during 2020 totaling 11 people. Or only 0.13 percent of the 1200 total population, which means it's still small. 
Table 4. Data Workers

\begin{tabular}{lc}
\hline \multicolumn{1}{c}{ Criteria } & Total \\
\hline Business Manager and employee & $8 \times 200$ citizens \\
Male \& female workers in group business & $10 \times 1200$ citizens \\
Workers at the Sea Cucumber Farming Business Company & 9 people x 1200 citizens \\
Pekerja pada Perusahaan BudidayaTeripang & 11 people \\
\hline
\end{tabular}

From table 4 above, it is known that there are 8 people who have the status as managers of sea cucumber enlargement businesses or... of the total residents of Benan Village. Then the number of workers, both male and female in the sea cucumber business individually and in groups, amounted to 9 people or.... of the total residents of Benan Village. While the workers who work at the IndovareInc., numbered 11 people or .... Of the total residents of Benan Village.

Every worker, both managers and workers in the Sea Cucumber business, both in individual and group businesses and those who work at the IndovariInc., receives wages as workers with the amount as shown in the following table..

Table 5. Data on Wages/Salary of Workers in Sea Cucumber Business

\begin{tabular}{lc}
\hline \multicolumn{1}{c}{ Criteria } & Total (Rp) \\
\hline Manager & Between \\
& IDR 1 -1.5 million / production \\
Sea cucumber cleaning worker. & IDR 1,300 per 500 head or \\
\multirow{2}{*}{ Worker at company } & IDR $130,000 / 500$ head \\
& IDR 4 million/monthor \\
& IDR $153,000 /$ day \\
\hline
\end{tabular}

The table above explains that there are 3 (three) groups, namely; First, workers are also owners. Second, limited workers are only needed during the sea cucumber cleaning process (skin, and entrails), the third, workers in the company. There are also local workers at the company, apart from workers who come from outside the Benan village. The total number of residents who work in this sea cucumber enlargement business is 22 people.

Table 6. Production / Harvest Sea Cucumbers Per-Breeding Period.

\begin{tabular}{lcc}
\hline \multicolumn{1}{c}{ Criteria } & Total & Percentage $(\%)$ \\
\hline The number of seeds stocked in one cage. & 1000 tails & 100 \\
Production/Harvest & 600 tails & 60 \\
\hline
\end{tabular}

Source: Data processed (2020)

From the table above, it is known that if the sea cucumber seeds are inserted at the same time with the same relative weight and size as many as 1000 fish, after 8-12 months they are harvested. The size of sea cucumbers is relatively different in size and weight. Of the 1000 sea cucumbers that are spread after a period of $8-12$ months later, only 60 percent can be harvested. 
From the results of interviews with researchers with the manager, some information was obtained why sea cucumbers with seeds are relatively the same in weight, size and size, but at harvest time it turns out that it cannot be carried out at once. The first information that. First; Sea cucumbers purchased from fishermen in the amount of 1000 fish are only measured randomly at the time of purchasing seeds, both size and weight. Second; The management has not fully maintained the (large) growth of sea cucumbers during rearing such as they have not given feed whether from flour, coconut dregs, and animal waste for sea cucumber food during the maintenance period. Fourth, the size of the mud is still shallow with excavation from the seabed only $30 \mathrm{~cm}$. so that when the sea water recedes, the sea cucumbers experience abnormal water temperatures.

In the research results, the degree of acidity $(\mathrm{pH})$ is an environmental parameter that also affects the growth of sea cucumbers as Ngurah (1988) in Bandjar et al. (1988) suggested that the growth of sea cucumbers is also influenced by the $\mathrm{pH}$ of the waters where the $\mathrm{pH}$ suitable for the growth of sea cucumbers is 6.50-7.50 for productive waters and 7.50-8.50 for very productive waters. The degree of acidity $(\mathrm{pH})$ at the study site ranged from 7.9-8.14 while that found by Padang et al. (2015b) in penculture around 8.10-8.46.

The growth rate of sea cucumbers when compared with Padang et al. (2015a, b) rearing sea cucumbers in penculture had a greater growth rate of $0.069 \%$ for two months and reached $0.14 \%$ after four months in rearing containers that were given chicken manure and Enhalusacroides seagrass leaves, while the daily growth rate sea cucumbers in penculture containers that were not given chicken manure and Enhalusaccoroides seagrass leaves were $-0.206 \%$ during two months of maintenance and reached $-0.40 \%$ after four months of rearing. Padang et al. (2014c) rearing sea cucumbers in controlled containers obtained a daily growth rate of $-0.367 \%$ on sediment media, $0.136 \%$ on sediment media and seagrass leaves and $-0.055 \%$ on sediment and Navicula sp.

\section{Conclusion}

This study resulted in several conclusions, including:

1. During 2020, there are 38 residents of Benan Village who work in the Sea Cucumber Farming business, in addition to those who work as fishermen and traders in general.

2. The managers earn an average income of 1 to 1.5 million/harvest from 500 sea cucumbers that are produced/harvested. Managers will earn between 4 to 4.5 million from 1000 sea cucumbers produced/harvested. Same with the income of the company's leaders in the city.

3. Workers in individual or group sea cucumber businesses will receive a wage of Rp. $1,500,000 / 500$ sea cucumbers, or Rp. 3,000 / head to clean the entrails and skin. Because there are 9 workers, each of them earns Rp. 167,000/harvest activity or per-500 sea cucumbers. And workers will get a wage of Rp. 333.333/person or the manager pays IDR 3,000,000 for 9 people. If workers are able to clean 1000 sea cucumbers in a maximum of 3-4 hours. Workers in the company receive wages in accordance with the $2021 \mathrm{UMP}$, which is 3,005,383 and can be more than the UMP.

4. The development of the sea cucumber business has an effect on the economy of the community (work) of Benan Village. 


\section{References}

[1] Akhirman (2020), PKM Dosen FE. UMRAH, 2020 "Pembinaan Usaha Pembesaran

[2] Teripang (KJT) POKWASMAS Desa Benan Kab.Lingga

[3] Arikunto, S. 2002. MetodologiPenelitianSuatuPendekatan Proposal. Jakarta: PT. RinekaCipta. Tjiptono (2001:27)

[4] Hutomo, H. (1997). Padang Lamun Indonesia JurnalPuslitbangOseanologi-LIPI. JakartaPurcell, 2014).

[5] Kaswandi et al. (2000), Lian et al. (2000) dan Kustiariyah et al. (2006) melaporkan bahan Aktif yang dihasilkan oleh Holothuriasp.Kustiariyah, 2007).

[6] Kustiariyah. 2007. Teripang Sebagai Sumber Pangandan Bioaktif. Buletin. Teknologi Hasil Perikanan. Vol X

[7] Martoyo et al. (2000) kandungan gizi teripang kering.

[8] Nurlaila Ervina Herliany., et al , 2016). ). Pemanfaatan teripang

[9] Padang A, Sangadji M, Lukman E, Subiyanto R. 2017. Growth and The Survival of Sandfish (Holothuriascabra) Reared in Floating Net Cages. JurnalTRITON . 13 : 115 124.

[10] PraptoDarsono (2007), Oseana, Volume XXXII, Nomor 2, Tahun 2007 : 1 - 10

[11] PT. Innovare MaricultureDevelopmet (2019) Data Perkembangan Hasil Budidaya

[12] Teripang Desa Pulau Benan Kec. Katang Bidare, Kab. Lingga.

[13] Sasongko dan Parulian., 2015., Anggaran. Jakarta: Salemba Empat.

[14] Sahin, S. Serin., 2010., Physics Learning Locus of Control in A Socio - Econm:. 4 halaman

[15] Sugiyono. (2017). Metode PenelitianKuantitatif, Kualitatif, dan R\&D. Bandung : Alfabeta, CV. 